\title{
Central bank reform, liberalization and inflation in transition economies- an international perspective ${ }^{\hbar}$
}

\author{
Alex Cukierman ${ }^{\mathrm{a}, *}$, Geoffrey P. Miller ${ }^{\mathrm{b}}$, Bilin Neyapti ${ }^{\mathrm{c}}$ \\ ${ }^{a}$ School of Economics, Tel-Aviv University, Tel-Aviv 69978, Israel, CentER, Tilburg University, Tilburg, \\ The Netherlands and CEPR \\ ${ }^{\mathrm{b}}$ School of Law, Department of Economics, New York University, New York, NY 10012, USA \\ ${ }^{\mathrm{c}}$ Department of Economics, Bilkent University, 06533 Bilkent Ankara, Turkey
}

Received 13 July 2000; received in revised form 20 March 2001; accepted 31 May 2001

\begin{abstract}
This paper develops extensive new indices of legal independence (central bank independence (CBI)) for new central banks (CBs) in 26 former socialist economies. The indices reveal that CB reform in the FSE during the 1990s has been quite ambitious. In spite of large price shocks, reformers in those countries chose to create CBs with levels of legal independence that are substantially higher, on average, than those of developed economies during the 1980s. The evidence in the paper shows that $\mathrm{CBI}$ is unrelated to inflation during the early stages of liberalization. But for sufficiently high and sustained levels of liberalization, and controlling for other variables, legal CBI and inflation are significantly and negatively related. These findings are consistent with the view that even high CBI cannot contain the initial powerful inflationary impact of price decontrols. But once the process of liberalization has gathered sufficient momentum legal independence becomes effective in reducing inflation. The paper
\end{abstract}

\footnotetext{
${ }^{2}$ This is a revised version of CEPR Discussion Paper number 2808, May 2001. Previous versions of the paper were presented at the June 1998 Fourth Dubrovnik conference on Transition Economies, and at the July 2001 Meeting of the Western Economic Association. We gratefully acknowledge the help of Maureen Brown, Robert Christiansen, Patrick Conway, Cevdet Denizer, Jan Fidrmuc, Alan Gelb, Joel Hillman, Ricardo Lago, Gideon Schurr and Andrezej Slawinski in assembling parts of the data set used. We also benefitted from the criticisms and suggestions of an anonymous referee, Vache Gabrielyan, Robert King, Ricardo Lago, Sergei Novik, Heikki Oksanen and Daniel Treisman.

The basic data underlying this paper appears in the four appendix tables and is available electronically.

*Corresponding author. Tel.: +972-3-6409-909; fax: +972-3-6409-908.

E-mail address: alexcuk@ccsg.tau.ac.il (A. Cukierman).
} 
also presents evidence on factors that affect the choice of CBI and examines the relation between inflation and CBI in a broader sample. (C) 2002 Elsevier Science B.V. All rights reserved.

JEL classification: E5; P2; K1; P16

Keywords: Central banks; Legal independence; Transition economies; Inflation; Reform

\section{Introduction}

The, still ongoing, process of transition from plan to market in the former socialist economies (FSE) involves a fundamental process of change in the structure of those economies. In their attempt to create the institutional infrastructure needed for a market economy governments of the FSE scrapped old institutions and replaced them with new ones that were often patterned after similar institutions in the Western democracies. One element of this process was the creation of a Western type central bank (CB). Practically, all FSE either created a totally new $\mathrm{CB}$ by breaking the, typically socialist, Monobank into a CB and a private banking system or, in the case of several Central and East European (CEE) countries, substantially upgraded the legal independence of their preexisting CBs. Within a span of 8 years (1991-1998) all FSE created completely new CB laws, or reformed existing laws, at least once and sometimes even twice. Although there are substantial cross country variations among these new CB laws practically all of them embody substantially higher levels of independence than was the case in the prereform period.

Prior to, and in some cases after, the enactment of the CB law most transition economies experienced high and variable inflation. In some cases those inflationary episodes even assumed hyperinflationary dimensions. ${ }^{1}$ The conjunction of high inflation and of $\mathrm{CB}$ reform provides a unique opportunity to examine the relationship between inflation and central bank independence (CBI) in environments with major structural changes and high inflation.

This paper has two major purposes. The first is to document and quantify the cross sectional and over time variation in the level of legal CBI in transition economies in a manner that allows systematic comparisons with the independence of CBs in more mature market economies. The second is to examine whether higher legal CBI is associated with lower inflation as is the case in developed economies. ${ }^{2}$ This negative association between inflation and legal independence is not obvious a priori for several reasons. First, as is the case in non-FSE developing countries, legal independence may be a poor proxy for actual independence because of substantial

\footnotetext{
${ }^{1}$ An informative overall summary of the evolution of inflation in FSE appears in Stern (1996).

${ }^{2}$ Early evidence on inflation and CBI appears in Grilli et al. (1991), Cukierman (1992), Cukierman et al. (1992) and Alesina and Summers (1993). Recent surveys of this and later work are Eijffinger and De Haan (1996) and Cukierman (1998).
} 
deviations between actual practice and the law. ${ }^{3}$ Second, although CBI may be negatively associated with inflation in relatively stable Western democracies it may not be sufficient to contain the inflationary impact of large price shocks such as those that are induced by price decontrols and armed conflicts. A recent study by de Melo et al. (1996) reports that inflation is lower in transition economies with a higher level of sustained liberalization. A third purpose of the paper is to examine the relative contributions, if any, of liberalization and of legal CBI to the abatement of inflation.

To this point there has been little systematic work on measuring legal CBI and its relation to inflation in the FSE. Two exceptions are the recent work of Loungani and Sheets (1997) who construct an index of legal independence for 12 FSE and relate it to the rate of inflation in those countries in 1993 and Neyapti (2002) who develops similar data for a sample of eight Central and East European countries between 1989 and 1996. ${ }^{4}$ This paper extends both samples along several dimensions. First, it includes 26 FSE and considers the association between inflation and CBI over the entire period between 1989 and 1998. ${ }^{5}$ Second, it provides indices for the detailed features of the new laws that are based on the codification system in Cukierman et al. (1992) and in Cukierman (1992, Chapter 19). This makes it possible to compare the level of independence of the newly created CBs with that of more established CBs in the world and to experiment with several alternative measures of independence.

The indices of independence developed in the paper reveal that the legal independence of newly created CB in the FSE is higher than that of CBs in developed economies during the 1980s. In particular, at least eight of the newly created CBs possess levels of aggregate legal independence that exceed that of the highly independent Bundesbank during the 1980s. The evidence in the paper also shows that inflation and legal independence are negatively related but only after the process of liberalization has been sufficiently strong and sustained.

The paper is organized as follows. Section 2 describes the methods used to construct detailed and aggregate indices of legal independence. It also presents the indices and puts them within an international context. Controlling for wars and the extent of sustained liberalization, Section 3 presents preliminary evidence on the relation between inflation and several aggregate indices of legal independence. The sample consists of a pooled cross section time series comprising three broad time periods; The period prior to the enactment of the first CB law, the period after the

\footnotetext{
${ }^{3}$ Such deviations led Cukierman et al. (1992), Cukierman (1992, Chapters 19 and 20), Cukierman and Webb (1995), Haan de and Van't Hag (1995) and Haan de and Kooi (1998) to use behavioral proxies of CBI such as the turnover of CB governors and their political vulnerability.

${ }^{4}$ See also Neyapti (1997). Radzyner and Riesinger (1997) contains an informative discussion of legal and of actual independence in 5 CEE. Related work on various small subsets of FSE appears in Hochreiter (1994), Hochreiter and Riesinger (1995) and in Hochreiter et al. (1996).

${ }^{5}$ Except for Bosnia-Herzegovina and (contemporary) Yugoslavia this is practically the entire universe of FSE.
} 
enactment of the last CB law and, for nine countries, a period between the enactment of a first and a second CB law. The main finding is that legal independence and inflation are unrelated.

Section 4 takes a deeper look at this lack of association by also controlling for the temporary, but powerful, inflationary shocks induced by price decontrols and by allowing for the potential existence of an interaction between legal independence and sustained liberalization. The main finding is that the familiar, from developed economies, negative relation between inflation and legal independence appears also in the transition economies, but only after the process of sustained liberalization crosses a certain threshold. Section 5 examines the relationship between inflation and legal independence in a wider sample that includes the transition countries and the developed economies. Section 6 tests empirically several hypotheses about possible determinants of legal CB independence. This is followed by concluding remarks.

\section{The measurement of legal $\mathrm{CBI}$ in economies in transition}

There are, by now, several alternative indices of legal CBI. The most comprehensive of those is the index in Cukierman et al. (1992) or in Cukierman (1992, Chapter 19). This index is based on a coding of 16 different characteristics of $\mathrm{CB}$ charters that pertain to the allocation of authority over monetary policy, procedures for resolution of conflicts between the CB and government, the relative importance of price stability in $\mathrm{CB}$ objectives as stated in the law, the seriousness of limitations on lending by the $\mathrm{CB}$ to government, and procedures for the appointment and dismissal of the governor of the CB. Cukierman et al. (1992) present a weighted index of those 16 characteristics (LVAW) and Cukierman (1992) presents an unweighted version of the same characteristics (LVAU).

Other indices, as those used by Bade and Parkin (1988), Alesina (1988, 1989), Grilli et al. (1991) and Eijffinger and Schaling (1993) can, for the most part, be approximated by subsets of the components of the LVAW (or of the LVAU) index. ${ }^{6}$ We therefore code the legal independence of new CB laws in FSE in terms of the 16 components underlying the LVAW and the LVAU indices. This has two advantages. First, given those 16 characteristics, it is possible to perform sensitivity analysis with respect to the other indices by using appropriate subsets of those characteristics. Second, the LVAW index exists for a wide number of countries during the 40 years preceding the breakdown of Communism. The coding of CBI in transition economies in terms of this index allows, therefore, a wide range of international comparisons of legal independence.

The 16 basic variables underlying the aggregate index LVAW and the references describing the conventions for their coding appear in Table 5 of the appendix. ${ }^{7}$

\footnotetext{
${ }^{6} \mathrm{~A}$ systematic comparison between the different indices appears in Eijffinger and van Keulen (1995).

${ }^{7}$ The index LVAW is obtained via a two rounds judgmental aggregation procedure in the first of which 16 various features of legal independence are aggregated into eight subgroups. Those eight subgroups are
} 
Each variable is coded on a scale between 0 and 1 where 0 stands for the minimal level of independence and 1 for the maximal level. Our sample consists of 26 countries that include all the countries that broke off from the former Soviet Union (FSU), Mongolia, and all the former socialist CEE countries except Bosnia and contemporary Yugoslavia. Table 1 shows (in the last three columns) alternative aggregate indices of legal CBI for those countries. In addition the second and third columns show the year(s) of enactment of the CB law(s) and, when relevant, the year of replacement of the Ruble by a domestic currency, respectively. In nine countries there were two $\mathrm{CB}$ reforms. In such cases the country holds two rows, each with a different enactment year where the first row stands for the first CB law enacted in that country and the second row for the second CB law.

In some FSU countries like Lithuania and Moldova the Ruble continued to circulate for some time after the enactment of the first CB law so that this law was not effective prior to the replacement of the Ruble by a domestic currency. Hence, in order to evaluate the impact of $\mathrm{CB}$ independence on inflation it is important to keep track of both the year of enactment of the law as well as of the year of replacement of the Ruble. This is the reason for the appearance of the second and third columns.

The table shows the aggregate index LVAW as well as two narrower indices labeled LVES and LVESX, respectively. The first index assigns positive weights only to the allocation of authority for monetary policy, the procedures for resolution of conflicts between government and the $\mathrm{CB}$, and the degree of relative focus on price stability as prescribed by the law. ${ }^{8}$ LVESX is a weighted average of the narrow LVES index and of the subaggregate of all limitations on lending by the CB to government from Cukierman et al. (1992) with weights of 0.6 and 0.4 , respectively. ${ }^{9}$ It is calculated directly from the individual components in Table 5 of the appendix. Among the CB laws exhibiting the highest levels of independence are those of Estonia, the Czech Republic, Belarus, and the latest laws of Lithuania, Armenia, Moldova and Poland. The last four laws have been enacted between 1995 and 1997.

\section{(footnote continued)}

then further aggregated to obtain the index LVAW. The weights used in the second and last round of aggregation are; appointment and dismissal procedures and term of office of the governor- 0.20 ; location of authority over monetary policy, CB objectives and severity of limitations on advances to government - 0.15 each; limitations on securitized lending, location of decision about CB lending and other miscellaneous feature of limitations on lending - 0.10 each; and the width of the circle of potential borrowers from the CB - 0.05. The indices LVAU and LVAW are highly correlated. Further detail appears in Section 19.3 of Cukierman (1992).

${ }^{8}$ The weights used are $0.4,0.4$ and 0.2 , respectively. This relatively narrow index follows the spirit of Eijffinger and Schaling (1993) and of Eijffinger and van Keulen (1995) who claim that those characteristics of legal independence are far more important for inflation than all the rest.

${ }^{9}$ This aggregate "legal limitations on lending" variable is a weighted average of eight different variables that pertain to the tightness of legal limitations on lending by the $\mathrm{CB}$ to government. The relative magnitudes of the weights are the same as those in Table 19.2 of Cukierman (1992, p. 380). The correlation coefficients between LVAW and each of the following: LVES, LVESX are 0.92 and 0.90 , respectively. The correlation between LVES and LVESX is 0.96 . 
Table 1

Aggregate legal independence in transition economies after CB reform and year of removal of the ruble

\begin{tabular}{|c|c|c|c|c|c|}
\hline Country & $\begin{array}{l}\text { Enactment } \\
\text { year }\end{array}$ & $\begin{array}{l}\text { Year of removal } \\
\text { of the Ruble }{ }^{\mathrm{a}}\end{array}$ & LVAW & LVES & LVESX \\
\hline Albania & 92 & & 0.51 & 0.47 & 0.49 \\
\hline Armenia & 93 & 93 & 0.30 & 0.60 & 0.34 \\
\hline Armenia & 96 & & 0.85 & 1.00 & 0.90 \\
\hline Azerbaijan & 92 & 94 & 0.22 & NA & 0.42 \\
\hline Azerbaijan & 96 & & 0.24 & NA & 0.37 \\
\hline Belarus & 92 & 94 & 0.73 & 0.75 & 0.67 \\
\hline Bulgaria & 91 & & 0.55 & NA & 0.65 \\
\hline Croatia & 92 & & 0.44 & 0.60 & 0.49 \\
\hline Czech Republic & 91 & & 0.73 & 0.96 & 0.73 \\
\hline Estonia & 93 & 92 & 0.78 & 0.96 & 0.58 \\
\hline Georgia & 95 & 93 & 0.73 & 0.68 & 0.62 \\
\hline Hungary & 91 & & 0.67 & 0.79 & 0.61 \\
\hline Kazakhstan & 93 & 93 & 0.32 & 0.63 & 0.56 \\
\hline Kazakhstan & 95 & & 0.44 & 0.92 & 0.79 \\
\hline Kyrgyz Republic & 92 & 93 & 0.52 & 0.55 & 0.55 \\
\hline Latvia & 92 & 93 & 0.49 & 0.96 & 0.73 \\
\hline Lithuania & 91 & 93 & 0.28 & 0.37 & 0.25 \\
\hline Lithuania & 96 & & 0.78 & 0.96 & 0.58 \\
\hline Macedonia & 95 & & 0.41 & 0.68 & 0.55 \\
\hline Moldova & 91 & 93 & 0.38 & 0.84 & 0.54 \\
\hline Moldova & 95 & & 0.73 & 0.96 & 0.94 \\
\hline Mongolia & 91 & & 0.43 & 0.96 & 0.61 \\
\hline Mongolia & 96 & & 0.55 & 0.92 & 0.68 \\
\hline Poland & 91 & & 0.46 & 0.49 & 0.32 \\
\hline Poland ${ }^{\mathrm{b}}$ & 97 & & 0.89 & 0.92 & 0.95 \\
\hline Romania & 91 & & 0.34 & 0.51 & 0.32 \\
\hline Russia $^{\mathrm{c}}$ & $93^{\mathrm{e}}$ & & 0.43 & 0.47 & 0.41 \\
\hline Russia & 95 & & 0.49 & 0.47 & 0.38 \\
\hline Slovak Republic & 92 & & 0.62 & 0.92 & 0.73 \\
\hline Slovenia & 91 & & 0.63 & 0.72 & 0.52 \\
\hline Tajikistan & 93 & 95 & 0.36 & NA & 0.29 \\
\hline Turkmenistan & 92 & 93 & 0.26 & 0.25 & 0.19 \\
\hline Ukraine $^{\mathrm{d}}$ & $91^{\mathrm{e}}$ & 93 & 0.42 & NA & NA \\
\hline Uzbekistan & $92^{\mathrm{e}}$ & 94 & 0.41 & NA & 0.71 \\
\hline Uzbekistan & 95 & & 0.56 & 0.92 & 0.92 \\
\hline Average & & & 0.51 & 0.73 & 0.57 \\
\hline \multicolumn{6}{|c|}{ Countries with two CB reforms - averages } \\
\hline First law & & & 0.36 & 0.62 & 0.46 \\
\hline Second law & & & 0.62 & 0.88 & 0.72 \\
\hline
\end{tabular}

${ }^{a}$ For obvious reasons this year is shown only for countries that used to be part of the former Soviet Union. The source of the information for this column is: Transition Report, EBRD, various issues.

${ }^{\mathrm{b}}$ All the limitation on lending variables underlying the 1997 aggregate index for the Bank of Poland are set to 1.00 because the 1997 Polish constitution prohibits government from borrowing at the CB. Further details and discussion appear in the second footnote to Table 5 in the appendix, in Wojtyna (1997) and in Huterski et al. (1999).

${ }^{\mathrm{c}}$ The first Russian central bank law was passed on December 1990 but apparently was applied only at the end of 1992 and was amended in 1993. In view of this, and since a new currency was introduced in July 1993 we picked 1993 as the year in which the first Russian central bank law became effective. See also note number 4 in Table 5 of the Appendix.

${ }^{\mathrm{d}}$ The narrower indices of legal independence for Ukraine are not shown in line with our rule not to display an aggregate index when the sum of weights of the constituent legal variables for which there is a meaningful entry is less than 0.7. As can be seen from Appendix table 5 data on some of the legal variables in Ukraine is available. Had we calculated narrow aggregate indices from this small set of legal variables we would have obtained indices showing a non negligible level of legal independence.

${ }^{\mathrm{e}}$ Tentative date. 
Why did those countries choose such high levels of independence? This is a question that concerns the sociology and politics of institution formation. Section 6 below offers a tentative discussion as well as preliminary evidence.

Late comers to the circle of CB reformers generally tend to enact laws with higher levels of independence. This feature is particularly striking in countries that had more than one CB reform like Armenia, Moldova, Azerbaijan, Kazakhstan, Lithuania, Poland and Mongolia. In all those cases the level of independence of the second law is higher than that of the first law, and frequently, by a lot. The figures at the bottom of Table 1 illustrate the average magnitude of this phenomenon. It is noteworthy that, in addition, the average level of independence of the first law in countries with two $\mathrm{CB}$ reforms is lower than the average level of independence in the entire sample but that their second laws embody a significantly higher level of independence than that of the sample average. Essentially, countries that had two CB reforms initially granted less than average independence to their CBs' but were then led to reconsider their positions. Once the authorities of those countries decided to have a second reform they went farther in terms of legal independence than countries that had only one $\mathrm{CB}$ reform.

The general trend in CB legislation illustrated by Table 1 is particularly dramatic in view of the fact that during the 40 years ending in 1989 there were very few changes in CB legislation. ${ }^{10}$ It appears, therefore, that the international monetary policy consensus during recent years has been shifting vigorously towards consideration of CBI as a highly desirable institutional feature. This conclusion is reenforced by the international comparison of legal independence presented in the following subsection.

\subsection{The legal independence of new CBs in transition economies - an international perspective}

This subsection compares the legal independence embedded in the (latest) CB laws in transition economies with that of developed economies during the decade of the 1980s. The most striking fact is that, on average, aggregate legal independence of new CBs in transition economies is substantially higher than CBI in developed economies during the 1980s. This conclusion is robust to the type of aggregate index used. For example, the average value of LVAW is 0.51 in transition economies and is merely 0.36 in developed economies. Similarly, the average value of LVES is a whopping 0.73 in transition economies against 0.29 in developed economies. ${ }^{11}$ Table 2 presents a common ranking of both groups of countries for the LVAW and

\footnotetext{
${ }^{10}$ Cukierman (1992, Chapter 19) and Cukierman et al. (1992).

${ }^{11}$ Since 1989 a number of developed economies (Belgium, France, Italy, Portugal, Spain, New-Zealand and the UK) have upgraded legal CBI (Cukierman, 1998). It is likely that even if those changes are taken into consideration average legal independence of central banks in transition economies will remain higher than that of developed economies.
} 
Table 2

A comparison of the new legal independence in transition economies and in developed economies during the 1980 s

(A) Ranked by $L V A W^{\mathrm{a}}$

\begin{tabular}{llllll}
\hline Country & LVAW & Country & LVAW & Country & LVAW \\
\hline Poland & 0.89 & Bulgaria & 0.55 & Iceland & 0.34 \\
Armenia & 0.85 & Kyrgyz Republic & 0.52 & Romania & 0.34 \\
Estonia & 0.78 & Albania & 0.51 & Luxembourg & 0.33 \\
Lithuania & 0.78 & Denmark & 0.50 & Sweden & 0.29 \\
Georgia & 0.73 & Latvia & 0.49 & Finland & 0.28 \\
Moldova & 0.73 & Russia & 0.49 & UK & 0.27 \\
Belarus & 0.73 & USA & 0.48 & Turkmenistan & 0.26 \\
Czech Republic & 0.73 & Canada & 0.45 & Azerbaijan & 0.25 \\
Germany & 0.69 & Croatia & 0.44 & Italy & 0.25 \\
Hungary & 0.67 & Ireland & 0.44 & France & 0.24 \\
Switzerland & 0.64 & Kazakhstan & 0.44 & New-Zealand & 0.24 \\
Slovenia & 0.63 & Netherlands & 0.42 & Spain & 0.23 \\
Slovak Republic & 0.62 & Ukraine & 0.42 & Japan & 0.18 \\
Austria & 0.61 & Macedonia & 0.41 & Belgium & 0.17 \\
Uzbekistan & 0.56 & Australia & 0.36 & Norway & 0.17 \\
Mongolia & 0.55 & Tajikistan & 0.36 & &
\end{tabular}

(B) Ranked by LVES ${ }^{\mathrm{a}}$

\begin{tabular}{llllll}
\hline Country & LVES & Country & LVES & Country & LVES \\
\hline Armenia & 1.00 & Macedonia & 0.68 & Turkmenistan & 0.25 \\
Estonia & 0.96 & Croatia & 0.60 & Norway & 0.21 \\
Latvia & 0.96 & Kyrgyz Republic & 0.55 & Finland & 0.16 \\
Lithuania & 0.96 & Denmark & 0.52 & Ireland & 0.16 \\
Moldova & 0.96 & Romania & 0.51 & USA & 0.16 \\
Czech Republic & 0.96 & France & 0.51 & Belgium & 0.08 \\
Poland & 0.92 & Russia & 0.47 & New-Zealand & 0.08 \\
Kazakhstan & 0.92 & Albania & 0.47 & Italy & 0.04 \\
Mongolia & 0.92 & Switzerland & 0.40 & Sweden & 0.04 \\
Slovak Republic & 0.92 & Netherlands & 0.37 & UK & 0.04 \\
Germany & 0.87 & Australia & 0.29 & Azerbaijan & NA \\
Hungary & 0.79 & Iceland & 0.29 & Tajikistan & NA \\
Austria & 0.76 & Japan & 0.27 & Ukraine & NA \\
Belarus & 0.75 & Canada & 0.25 & Uzbekistan & NA \\
Slovenia & 0.72 & Luxembourg & 0.25 & Bulgaria & NA \\
Georgia & 0.68 & Spain & 0.25 & & \\
\hline
\end{tabular}

${ }^{\text {a }}$ In countries with two $\mathrm{CB}$ reforms the latest of the two laws is used.

NA means that there is not enough information to calculate the index. We followed the rule of not reporting an aggregate index whenever information on more than 30 percent of the (weighted) constituent components was missing.

the LVES indices. For the first index the eight countries with the highest scores are all transition economies, followed by high-independence countries among developed nations like Germany and Switzerland. For the second index the first 10 countries 
with the highest score are all transition economies. The immediately following entries down the ranking are largely taken, again, by the CBs of countries in transition.

It is evident from the table that, sometimes amidst high inflation, political authorities in transition economies made significant efforts to create CBs with high legal independence by international standards. This raises two, possibly related, questions. First, does the difference in legal independence between the two groups of countries reflect a similar difference in actual CBI? Second, why did the political authorities of transition economies rush to delegate so much legal independence to their CBs? Our feeling with respect to the first question is that the difference in legal independence between the two groups of countries exaggerates the relative actual independence of transition economies, particularly during the early stages of transition from planned to market economies. One reason is that the translation of legal independence into actual independence depends on the general regard for the law which is likely to be higher in developed economies with a long democratic and free markets tradition than in the newly created transition democracies. But as the process of sustained liberalization persists and gathers momentum it is likely that this relative bias shrinks. We return to this issue in Section 4.3. As to the second question an important consideration is the realization on the part of policymakers in the FSE that CBI can substantially enlarge the, initially rather limited, access of their countries to international capital markets. In the world of the 1990s CBI is a stamp of economic respectability and for some countries even a prerequisite for access to those markets. It is also likely that the success of the Bundesbank in maintaining price stability and the increasing professional consensus that $\mathrm{CBI}$ is conducive to price stability played a role.

\section{Legal independence and post-enactment inflation - a first look}

Most existing studies on inflation and CBI in developed and developing countries excluding the transition economies are basically cross-sectional. This purely cross sectional focus is dictated by the absence of meaningful temporal variation in existing measures of legal CBI. But in the case of transition economies there were, during the early 1990s, dramatic changes in CBI within all the countries concerned. In many cases new CBs were created from scratch and were granted, as we saw in Section 2, substantial levels of legal independence.

Did the enactment of new CB laws have a noticeable effect on inflation, and was the decrease in inflation bigger in countries that experienced a larger increase in the legal independence of their CB? Those questions can be answered empirically by utilizing the over time variation, as well as the cross country variation in legal independence. For that purpose we divided the sample, for most countries, into two broad periods; a pre-enactment period and a post-enactment period. For countries that had two CB reforms, the sample was divided into three subperiods. The period prior to (and including the year of) the first enactment, the period after the first enactment up to and including the year of the second one, and the period after the enactment of the last CB law. 
In some of the FSU countries like Lithuania, Moldova and Tajikistan the first CB law was enacted prior to the replacement of the Ruble by a domestic currency. ${ }^{12}$ As a result, the new $\mathrm{CB}$ law did not become effective until the time of replacement of the Ruble by a domestic currency. In such cases the last year of the first period is taken to be the latest of the year of enactment of the CB law and of the year of replacement of the Ruble by a domestic currency. We thus obtain a pooled cross section - time series sample with, at most, 3 periods for each country.

Aggregate legal independence after the enactment of either the first or the second CB law is taken from Table 1. Prior to the first enactment or the replacement of the Ruble by a domestic currency (whichever comes later) it is characterized by the level of independence of the Russian $\mathrm{CB}$ for all the countries that broke off from the former Soviet Union as well as for Mongolia. ${ }^{13}$ Russia had two CB laws. The first apparently became effective in 1993 and the second in 1995. Prior to the first law CBI in Russia is taken to be zero. Data on pre-enactment CBI for Hungary, Poland, Romania and countries that broke off from the former Yugoslavia is the same as the legal independence in those countries during the eighties and is constructed from data in Cukierman et al. (1992) or in chapter 19 of Cukierman (1992). For the remaining CEE countries, for which there is no data, it is taken to be zero. ${ }^{14}$ Characterization of pre-enactment CBI as zero for countries that broke off from the former Soviet Union prior to (the earlier of) the introduction of a national currency or the first Russian CB law, is natural in view of the fact that there was no separate CB in the Soviet Union. Admittedly, there was a Monobank (the Gosbank) but its function was to finance the transactions that were implied by the central plan rather than to function as a $\mathrm{CB}$ in the Western sense.

Inflation is characterized by the rate of depreciation in the real value of money $(D)$ which is naturally bounded between zero and one. This measure has two advantages over the rate of inflation. First, it diminishes the influence of outliers. This is an important consideration in a sample of countries with wide variations in inflation, as is the case here. Second, $D$ is a more meaningful measure of the impact of inflation on individuals than the rate of inflation. This consideration is not important at low rates of inflation since at low rates the divergence between the two measures is negligible. But at high rates, of the kind that have been experienced by a good number of countries in our sample, the divergence becomes significant. ${ }^{15} D$ in year $t$ is calculated from data on inflation using the relation $D=F /(1+F)$ where $F$ is the

\footnotetext{
${ }^{12}$ An informative discussion of the process of replacement of the Ruble by domestic currencies appears in Melliss and Cornelius (1994) and Conway (1995).

${ }^{13}$ In two countries - Azerbaijan and Uzbekistan - this classification method leads to the creation of four periods. In order to maintain the sample within a format of, at most three periods, we aggregated the last two periods for Azerbaijan, and the first two periods for Uzbekistan by assigning the averages of the subperiods to each of the combined periods.

${ }^{14}$ Those countries are Albania, Bulgaria, the Czech Republic and the Slovak Republic. Experimentation with the alternative assumption that in all those countries pre-enactment legal independence was the same as the highest level of legal independence for the CEE countries for which there is pre-enactment data did not materially affect the nature of the results.

${ }^{15}$ For example when inflation is 100 percent the rate of depreciation in the real value of money is only 50 percent.
} 
average rate of inflation between year $t-1$ and year $t$. Data on average yearly inflation are obtained from various issues of the EBRD Transition Report and Update (data and detailed references appear in Table 6 of the appendix).

The rate of depreciation in the real value of money within each subperiod is taken as a simple yearly average within the subperiod. It is likely that, even if it has any impact on inflation, CB reform operates with a lag. Higher independence is likely to affect policy choices with some lag and those choices impact the economy with an additional lag. The construction of periods in our sample builds in a lag by including the year of enactment of a CB reform in the period that precedes this reform. As a consequence the average rate of depreciation in the real value of money in a country during any given subperiod is automatically related to the level of CBI that became effective at least one year in the past. This procedure also reduces the risk of simultaneity bias due to possible reverse causality from inflation to legal CBI. ${ }^{16}$ Simple regressions of $D$ on each of the three indices of legal independence without any controls yield negative and highly significant coefficients (at the 0.001 level) with values of adjusted $R^{2}$ ranging from 0.11 to $0.13 .^{17}$

However, there is reason to believe that other factors like the extent of liberalization, wars and price decontrols also exerted an influence on inflation in the FSE. In particular, recent work by de Melo et al. (1996) suggests that inflation is negatively related to the extent and the persistence of liberalization of the economy which they measure by an index of cumulative liberalization. The cumulative degree of liberalization (CLI) in a given year is defined as a simple sum of the degrees of liberalization (LI) up to and including the current year. The yearly liberalization index is, in turn, a weighted average (with weights of $0.3,0.3$ and 0.4 ) of the degrees of liberalization in the following areas: internal markets $(I)$, external markets $(E)$ and private sector entry $(P) .{ }^{18}$ The rationale for using a cumulative, rather than a yearly, index of liberalization is that at any given time economic performance is affected by the degree of liberalization at that time, as well as by the length of time that particular reforms have been in effect. When looking for a potential relationship between inflation and legal CBI it is therefore natural to control for the CLI. We measure the degree of cumulative liberalization within a subperiod as the value of CLI at the median year within the subperiod. ${ }^{19}$

\footnotetext{
${ }^{16}$ Further discussion of this issue appears in Section 6.

${ }^{17}$ Similar regressions of $D$ on the same indices of legal independence for the developed countries during the 1980s also yield negative coefficients. But those coefficients are not quite significant and the adjusted $R^{2}$ are relatively low (between 0.03 and 0.08 ). Thus, in the absence of controls the negative relation between inflation and legal independence is more in evidence in the panel of FSE during the 1990s than in the cross section of developed countries during the 1980s.

${ }^{18} I$ measures the extent of liberalization of domestic prices and abolition of state trading monopolies, $E$ measures the degree of liberalization of the foreign trade regime including the extent of currency convertibility and $P$ measures the extent of enterprise privatization and of banking reform. As is the case with the aggregate liberalization index each of those indices is bounded between zero and one. The yearly values of CLI appear in Table 7 of the appendix.

${ }^{19}$ When the number of years in a subperiod is even CLI for the subperiod is characterized by the mean value of CLI in the two years in the middle of that subperiod.
} 
Eight out of the 26 countries in the sample were involved in regional conflicts for at least part of the time span of our sample. Those countries are Croatia, Slovenia, Armenia, Georgia, Moldova, Azerbaijan, Tajikistan and Macedonia. Both theory and evidence suggest that deficits and inflationary finance are higher during wars. ${ }^{20}$ To account for possible effects of war on inflation we construct a war dummy (WD) that assumes a value of one in those countries-periods in which the country was at war for more than half of the time during the period $(1,2$ or 3$)$ and zero otherwise. ${ }^{21}$ The three periods data matrix used in this section is summarized in Table 8 of the appendix.

Preliminary regressions (not shown) of $D$ on CLI, the WD and the three aggregate indices of legal CBI from Table 1 confirm the de Melo et al. (1996) result that inflation is significantly lower the higher and the more persistent is the degree of liberalization as measured by the variable CLI and reveal a positive and significant influence of war on inflation. But the impact of all three indices of CBI on inflation is insignificant. Should we conclude from those preliminary results that, in the presence of controls, $\mathrm{CB}$ reform in the transition economies did not have any desirable effect on inflation? It is argued in the next section that reaching such a conclusion solely on the basis of this evidence is likely to be premature.

\section{Accounting for the inflationary impact of domestic price liberalization and of interactions between $\mathrm{CB}$ reform and liberalization}

\subsection{Effect of domestic price liberalization}

The process of decontrol of domestic prices produced sizable temporary nonmonetary jumps in the rate of inflation of many transition economies as prices of domestic goods were allowed to adjust towards market values. CB reform was often introduced just prior to, or concurrently with, the liberalization of domestic prices. It is likely that in such cases CBI cannot offset the temporary impact of price decontrol on the measured rate of inflation. Even if substantial, CBI alone is insufficient to contain the, temporary but powerful, price level adjustments that are essential to the process of liberalization of internal prices. It is therefore possible, in principle, that in spite of the fact that legal CBI does have a negative impact on inflation in the transition countries, this effect is not detected by the preliminary regressions because of the price shocks created by the process of decontrol of domestic prices.

To examine this possibility we add the index of liberalization of internal prices, $I$, from de Melo et al. (1996) to the preliminary regressions. Within each subperiod the value of $I$ is taken as its value in the median year(s) of the subperiod. To also control

\footnotetext{
${ }^{20}$ See for examples Barro (1979), Barro (1984, Chapter 15) and Roubini and Sachs (1989).

${ }^{21}$ A consequence of this classification is that all the periods for Macedonia are classified as "no war" periods since the 1991 armed conflict in that country was very brief.
} 
Table 3

Inflation, CBI, liberalization, wars and decontrols of domestic prices and currency boards without and with a zero constraint on the effect of $\mathrm{CBI}$ on inflation for $\mathrm{CLI}<3.0^{\mathrm{a}}$

Dependent variable: $D$

\begin{tabular}{|c|c|c|c|c|c|c|}
\hline \multirow{2}{*}{$\frac{\text { Regressors: }}{\text { CLI }}$} & \multicolumn{3}{|c|}{ Without a zero constraint } & \multicolumn{3}{|c|}{ With a zero constraint } \\
\hline & $\begin{array}{r}-0.13 \\
(0.00)\end{array}$ & $\begin{array}{r}-0.12 \\
(0.00)\end{array}$ & $\begin{array}{r}-0.12 \\
(0.00)\end{array}$ & $\begin{array}{r}-0.05 \\
(0.16)\end{array}$ & $\begin{array}{r}-0.03 \\
(0.28)\end{array}$ & $\begin{array}{r}-0.05 \\
(0.11)\end{array}$ \\
\hline$I$ & $\begin{array}{c}0.36 \\
(0.01)\end{array}$ & $\begin{array}{c}0.43 \\
(0.01)\end{array}$ & $\begin{array}{c}0.42 \\
(0.01)\end{array}$ & $\begin{array}{c}0.31 \\
(0.02)\end{array}$ & $\begin{array}{c}0.32 \\
(0.01)\end{array}$ & $\begin{array}{c}0.32 \\
(0.01)\end{array}$ \\
\hline WD & $\begin{array}{c}0.15 \\
(0.01)\end{array}$ & $\begin{array}{c}0.15 \\
(0.01)\end{array}$ & $\begin{array}{c}0.14 \\
(0.02)\end{array}$ & $\begin{array}{c}0.12 \\
(0.03)\end{array}$ & $\begin{array}{c}0.13 \\
(0.02)\end{array}$ & $\begin{array}{c}0.12 \\
(0.03)\end{array}$ \\
\hline LVAW & $\begin{array}{c}0.19 \\
(0.27)\end{array}$ & & & $\begin{array}{r}-0.47 \\
(0.00)\end{array}$ & & \\
\hline LVES & & $\begin{array}{c}0.00 \\
(0.97)\end{array}$ & & & $\begin{array}{r}-0.45 \\
(0.00)\end{array}$ & \\
\hline LVESX & & & $\begin{array}{r}-0.00 \\
(0.98)\end{array}$ & & & $\begin{array}{c}-0.41 \\
(0.00)\end{array}$ \\
\hline $\mathrm{DCB}$ & $\begin{array}{r}-0.06 \\
(0.67)\end{array}$ & $\begin{array}{r}-0.02 \\
(0.90)\end{array}$ & $\begin{array}{r}-0.03 \\
(0.83)\end{array}$ & $\begin{array}{c}0.06 \\
(0.66)\end{array}$ & $\begin{array}{c}0.07 \\
(0.57)\end{array}$ & $\begin{array}{r}-0.05 \\
(0.67)\end{array}$ \\
\hline Intercept & $\begin{array}{c}0.39 \\
(0.00)\end{array}$ & $\begin{array}{c}0.38 \\
(0.00)\end{array}$ & $\begin{array}{c}0.37 \\
(0.00)\end{array}$ & $\begin{array}{c}0.39 \\
(0.00)\end{array}$ & $\begin{array}{c}0.37 \\
(0.00)\end{array}$ & $\begin{array}{c}0.39 \\
(0.00)\end{array}$ \\
\hline Adj. $R^{2}$ & 0.41 & 0.43 & 0.40 & 0.50 & 0.57 & 0.50 \\
\hline Number of observations & 56 & 56 & 60 & 56 & 56 & 60 \\
\hline
\end{tabular}

${ }^{a}$ Numbers in parentheses under the coefficients are levels of significance.

for the possible effect of currency boards on inflation we add a currency board dummy (DCB) which assumes a value of one in country/periods in which a currency board was in effect for more than half of the period and zero otherwise. ${ }^{22}$ The results appear in the first three columns of Table 3. In comparison to the preliminary regressions the addition of this variable leads to a non-negligible increase in the overall explanatory power of the regressions (the adjusted $R^{2}$ 's increase, by over $20 \%$ to a range of $0.40-0.43$ ). It is apparent from the table that $I$ has a positive and highly significant effect on inflation but the coefficients of all three alternative measures of aggregate legal independence are still insignificant. As in the preliminary regressions the index of cumulative liberalization is still negative and significant and the WD still positive and significant.

The general picture that emerges from the first three columns of Table 3 leads to the conclusion that the process of decontrol of domestic prices has a significant positive impact on measured inflation and that, in the presence of controls, there is no evidence to support conventional wisdom regarding the negative relation between inflation and legal CBI.

\footnotetext{
${ }^{22}$ This dummy assumes a value of one in the last periods of Estonia and Lithuania and zero in all other cases. Details on precise times of currency boards appear in Kurt Schuler's home page.
} 


\subsection{Interaction between $C B$ reform and cumulative liberalization}

A possible reason for the lack of evidence in favor of a negative relation between inflation and legal independence is that such independence is instrumental in reducing inflation only when other structural features of the economy have become sufficiently and persistently similar to those of developed market economies. A fuller discussion of why this might be the case appears in Section 4.3. To examine this possibility we reestimate the first three regressions in Table 3 with a slope dummy at high values of the cumulative liberalization index. ${ }^{23}$ The slope dummy is meant to allow the detection of an interaction between the effects of independence and of liberalization on inflation if such interaction exists. The slope dummy measures the additional effect of legal independence on inflation when the cumulative liberalization index is higher than a given threshold. We experimented with three thresholds values; $\mathrm{CLI}=2.0,2.5,3.0$. The lowest threshold leaves a similar number of observations on either side of the threshold, and the highest leaves about a third above it.

The addition of the slope dummy on legal CBI induces a further increase in goodness of fit. The most striking result associated with this addition (not shown) is that the slope dummy is negative and highly significant pointing to the existence of a substantial difference between the impacts of CBI on inflation at low and at high levels of cumulative liberalization. The total impact of CBI on inflation for values of CLI above the threshold as characterized by the sum of the coefficient of CBI and of the corresponding slope dummy is insignificant for the lowest threshold. For the remaining thresholds the total impact is not significant for the broad index of CBI (LVAW) but it is significantly negative for the two narrower indices. ${ }^{24}$ It will be recalled that the first of the narrow indices (LVES) considers only the allocation of authority over monetary policy, the procedures for the resolution of conflicts and the importance of price stability as relevant for CBI. The second index (LVESX) also takes the seriousness of limitations on lending to government into consideration.

In light of these results we reestimated the first three regressions in Table 3 with a zero constraint on the slope of legal independence for observations with values of the cumulative liberalization index that are lower than the two higher thresholds $(C L I=2.5,3.0)$. This procedure isolates the impact of CBI on inflation at high levels of sustained liberalization. Results for the 3.0 threshold appear in the last three columns of Table 3. Allowing the effect of legal independence to operate only at high levels of cumulative liberalization induces a further non negligible increase in goodness of fit as can be seen by comparing the adjusted $R^{2} \mathrm{~s}$ of the first and the last three columns in the table. All the legal variables are now negative and highly

\footnotetext{
${ }^{23}$ Technically a dummy variable that assumes the value of one when CLI is above some threshold and the value of zero otherwise is defined. It is then used to create an additional variable that is defined as the product of the (appropriate) aggregate legal independence index and the previously defined dummy.

${ }^{24}$ Due to some doubts about the extent to which the First Russian CB law was effective we also tried a version of this experiments which classifies the data as if Russia had only one CB law-in 1995. The qualitative results were similar.
} 
significant. The impact of cumulative liberalization remains negative but is no longer significant at conventional levels. The impact of price decontrols and of wars remain positive and significant and that of currency boards remains insignificant. Results for the 2.5 threshold are qualitatively similar.

\subsection{Summary and discussion}

The main conclusion from Table 3 is that, in the presence of controls, the negative relation between legal independence and inflation found in Western Democracies also appears in the FSE but only above a certain threshold of sustained liberalization. At levels of sustained liberalization below the threshold, legal CBI has no impact on inflation while cumulative liberalization does have a strong negative impact. By contrast, at levels of cumulative liberalization above the threshold, CBI has a negative, usually significant, impact on inflation and the (still negative) impact of CLI on inflation becomes weaker.

At first blush this finding may appear surprising. Why should CBI be more effective in containing inflation at higher than at lower levels of cumulative liberalization? A possible reason is that at high levels of sustained liberalization general compliance with the law, including in particular the CB law is higher. As a consequence, for any given level of legal independence, the effective level of independence is higher the higher the level of sustained liberalization.

This begs the question of why compliance with the law should be higher in countries with higher levels of sustained liberalization. A possible reason is that the importance of law abidance for the orderly functioning of the economy and of the political system increases with the degree of sustained liberalization. This notion can be illustrated by considering the polar cases of a pure market economy and of a command economy. Law abidance is important for stopping a market economy from deteriorating into chaos by setting and enforcing clear rules of the game in order to limit opportunistic behavior by a large mass of independent agents. By contrast in a command economy, since the freedom of action of most agents is severely limited in the first place, law abidance is not as essential.

\subsection{Comparison to Loungani and Sheets}

Recently Loungani and Sheets (1997) examined the relation between the logarithm of inflation in 1993 and an index of independence they developed for a sample of 12 FSE. Loungani and Sheets find a negative relation between those two variables. ${ }^{25}$ Our sample is wider than theirs in terms of both countries and time periods covered. Since we use a number of CBI indices that differ from theirs it is of some interest to examine the sensitivity of the results they obtain using their sample of countries

\footnotetext{
${ }^{25}$ The countries in their sample are: Albania, Armenia, Bulgaria, the Czech Republic, Estonia, Hungary, Kazakhstan, Lithuania, Poland, Romania, Russia and Ukraine. They construct an index of legal independence from more basic data collected by Hinton-Braaten (1994) and Lewarne (1995).
} 
with our indices and broader time periods. This was done by reestimating the inflation equations with and without the interaction with CLI for 9 out of their 12 countries. ${ }^{26}$ Although in all cases the coefficient of aggregate legal independence is negative, it is never significant. Nor is there a significant impact of the interaction term. When the same experiment is repeated only for the periods after the enactment of the second $\mathrm{CB}$ law for the same nine countries the (negative) interaction between legal independence and cumulative liberalization becomes significant in some cases.

\section{Inflation and legal $C B$ independence in an international sample}

This section makes a step towards a broader examination of the relation between inflation and legal independence by examining this relationship in a sample that combines the (up to) three periods sample of transition economies used in the previous section with data on inflation and CBI within the developed economies during the $1980 \mathrm{~s}^{27}$ This data merging yields a sample of up to 79 observations. Two sets of regressions are run. In the first set inflation is related only to the aggregate indices, LVAW and LVES, of legal independence without controlling for other variables. The second set controls for the effects, in transition economies, of factors like price decontrols, wars and the degree of sustained liberalization. Results are summarized in Table 4.

It is apparent from the first two columns of the table that, in the combined sample, legal independence (whether measured by the broad index LVAW, or the narrow index LVES) has a negative and significant effect on inflation but that the overall goodness of fit is low. Results in the presence of additional factors appear in the last two columns. All variables, including the indices of legal CBI, have the expected signs and are highly significant. It is noteworthy that the inclusion of the controls for the transition countries leads to a substantial increase in the overall goodness of fit without affecting the significance of the negative impact of CBI on inflation. Experimentation with an interaction term between the index of cumulative liberalization and aggregate independence (not shown) does not yield a significant coefficient for the interaction term, but does yield again a negative and significant coefficient for the indices of legal independence.

In summary, the results with the international sample yield further support for the view that, in spite of the fact that legal independence does not always fully translate

\footnotetext{
${ }^{26}$ This is due to data limitations.

${ }^{27}$ The data on the developed economies is taken from Cukierman et al. (1992). Although data on CBI in developing countries during the 1980s is available we do not include those countries in the sample since previous studies show that legal independence was a very poor proxy for actual independence in those countries at that time (Cukierman et al., 1992 and Cukierman, 1992, Chapter 20). Those studies found no relation between legal independence and inflation in developing countries which led them and others to use behavioral proxies of independence like CB governors' turnover or a measure of the political vulnerability of the CB governor in the face of political change (Cukierman and Webb, 1995). The development of such measures for the transition countries is beyond the scope of this study.
} 
Table 4

Inflation and legal CBI - an international sample ${ }^{\mathrm{a}}$

Dependent variable: $D$

Regressors:

\begin{tabular}{|c|c|c|c|c|}
\hline LVAW & $\begin{array}{r}-0.34 \\
(0.00)\end{array}$ & & $\begin{array}{r}-0.37 \\
(0.00)\end{array}$ & \\
\hline LVES & & $\begin{array}{c}-0.15 \\
(0.07)\end{array}$ & & $\begin{array}{r}-0.23 \\
(0.02)\end{array}$ \\
\hline CLI & & & $\begin{array}{r}-0.11 \\
(0.00)\end{array}$ & $\begin{array}{r}-0.13 \\
(0.00)\end{array}$ \\
\hline$I$ & & & $\begin{array}{c}0.73 \\
(0.00)\end{array}$ & $\begin{array}{c}0.82 \\
(0.00)\end{array}$ \\
\hline WD & & & $\begin{array}{c}0.11 \\
(0.05)\end{array}$ & $\begin{array}{c}0.15 \\
(0.01)\end{array}$ \\
\hline Intercept & $\begin{array}{c}0.44 \\
(0.00)\end{array}$ & $\begin{array}{c}0.37 \\
(0.00)\end{array}$ & $\begin{array}{c}0.29 \\
(0.00)\end{array}$ & $\begin{array}{c}0.25 \\
(0.00)\end{array}$ \\
\hline Adj. $R^{2}$ & 0.10 & 0.03 & 0.43 & 0.44 \\
\hline Number of observations & 84 & 79 & 83 & 78 \\
\hline
\end{tabular}

${ }^{a}$ The international sample includes most of the developed economies during the eighties and our sample of 26 transition economies in the pre- and post-CB law enactment periods, as well as an "in between laws period" for transition countries that had two CB law reforms.

Numbers in parentheses under the coefficients are levels of significance.

into actual independence, it is nonetheless associated with significantly lower inflation. $^{28}$

\section{Determinants of legal independence}

Although all FSE enacted CB laws with relatively high levels of independence some countries went in this direction more than others. This section takes a brief look at possible reasons for this cross country variation in the level of independence. Eyeballing of the data reveals that many of the high-independence countries have a geographical or cultural closeness to Western Europe and to Germany in particular (Estonia, the Czech Republic and Lithuania), or have a very recent CB law (Georgia, Lithuania, Armenia and Moldova). These observations lead to a number of tentative hypotheses regarding the factors that are conducive to higher CBI. First, it is

\footnotetext{
${ }^{28}$ We saw in Section 3 that, in the absence of controls, the relation between inflation and legal independence is substantially stronger in the panel of FSE than in the cross section of developed economies during the 1980s. The fact that the first two simple regressions that combine both samples also yield significant coefficients is consistent with the view that those regressions are dominated by the relatively larger sample of FSE. The significant effect of legal independence in the last two regressions that introduce controls for the FSE is consistent with the view that, in spite of the fact that they have on average higher CBI and higher inflation than developed economies, after controlling for other variables, transition economies with higher CBI also have lower inflation.
} 
possible that the cultural impact on countries that are nearer to Western Europe is stronger. To examine this hypothesis we regressed the various indices of legal independence on the distance between the capital city of each of the countries in the sample and Berlin.

Another possibility is that the formal preconditions for joining the EMU might have induced the countries on the fast tracks to join the monetary union to grant more independence. The reason is that one of the preconditions for joining is, according to the Maastricht Treaty, a sufficiently high level of CBI. Poland, Hungary, Slovenia and the Czech Republic are on the first fast track to join the EMU and the Slovak Republic, Rumania, Bulgaria, Lithuania and Latvia are on a second fast track to join it. To test for the possible effect, on the choice of legal independence, of being on either one of the two fast tracks to join the EMU we added two dummy variables to the regression. The first dummy (second) assumes a value of one if the country is on the first (second) fast track to join the EMU and zero otherwise. To test for the possibility that the level of independence granted is higher the later is the time of reform we also added a regressor that measures the difference between the year of enactment of the CB law and 1990. Finally, to examine the possibility that countries with stronger inflationary experiences tend to, subsequently, delegate more authority to the $\mathrm{CB}$ we added the average value of inflation in the years prior to and including the year of enactment of the CB law to the regressions. More precisely, two versions of the average lagged inflation variable were tried. One that includes the year of enactment and one that excludes it.

The evidence from the first set of regressions suggests that being on the first (but not on the second) fast track to join EMU usually has a significant and positive impact on the level of legal independence chosen. The number of years that elapsed between the year of enactment of the law and 1990 also has a positive and (for some of the aggregate legal indices) significant effect on independence but all the remaining variables, including inflation, are insignificant. In the second set of regressions all variables, except for the lagged average value of inflation which turned out negative and significant, were insignificant. The negative sign of lagged inflation is obviously inconsistent with the view that the authorities of countries with higher inflation subsequently delegated more authority to their central banks.

\section{Concluding remarks}

The creation, from scratch, of new CBs in the FSE provides a natural experiment for examining the extent of $\mathrm{CB}$ reform, its sociology and the relation between $\mathrm{CBI}$ and inflation in an environment characterized by fundamental structural reform.

This paper develops extensive new data on the legal independence of CBs in the post CB reform period in the FSE. The new data is constructed in a manner that makes it comparable to earlier data on CBI in the industrial democracies and in, non-FSE developing countries. The data indicates that CB reform in the FSE during the 1990s has been quite ambitious. In spite of the large price shocks induced by the transformation from plan to market, or perhaps because of them, reformers in those 
countries chose to create CBs with levels of legal independence that are substantially higher, on average, than those of developed economies during the 1980s. But since it is likely that the average level of compliance with the law in the FSE is lower than compliance with it in Western democracies the discrepancy in actual independence may not be as large as appears to be the case from this comparison.

Taken to the extreme, and in view of the large price shocks caused by liberalization, the preceding observation could lead to the hypothesis that differences in legal independence among the different FSE should not matter much for inflation. The evidence in this paper suggests that such a conclusion is too extreme. Controlling for other variables CBI is indeed unrelated to inflation during the early phases of liberalization. But for sufficiently high and sustained levels of liberalization, and controlling for wars and price liberalization, legal CBI and inflation are usually significantly and negatively related. These findings are consistent with the view that legal CBI, no matter how high, cannot contain the powerful inflationary impacts of price decontrols and of the liberalization of foreign trade and of the exchange rate. But once the process of liberalization has gone far enough legal independence turns out to be effective in slowing inflation down. The evidence also suggests that the negative association between CBI and inflation is stronger for narrow indices of independence that focus on the allocation of authority over monetary policy, the procedures for the resolution of conflicts, the focus on price stability and the seriousness of limitations on lending to government.

The cumulative index of liberalization developed by de Melo et al. (1996) exerts a significant negative influence on inflation, as is the case in their paper, mainly at low levels of cumulative liberalization. Interestingly, at high levels of cumulative liberalization, after a sufficiently sustained experience with the new liberalized institutions has accumulated, CBI becomes relatively more important in keeping inflation down and cumulative liberalization becomes less significant. One possible explanation for the increase in the effectiveness of CBI at high levels of cumulative liberalization is that law abidance in transition economies rises with the level of cumulative liberalization. As a consequence the discrepancy between the relatively high legal independence of the CBs of economies in transition and their actual independence shrinks - and legal independence becomes more effective in keeping inflation at bay. A non negligible number of FSE have recently reached a range of values of cummulative liberalization for which CBI does have a significant moderating effect on inflation (see Table 7 of the appendix). After controlling for CBI, cumulative liberalization, wars and price decontrols, the evidence does not support the view that countries with currency boards enjoy lower rates of inflation.

Examination of the relation between inflation and legal independence in an international sample composed of the transition and of the developed economies strengthens the conclusion that legal independence and inflation are negatively related internationally.

Nine out of the 26 FSE in our sample had two CB reforms. The average level of independence of the first law in those countries was usually lower than the average 
level of independence in countries with only one CB reform. This was often followed by very high inflation in the countries with two reforms and then by enactment of a second CB law. The average level of independence embodied in the second law is substantially higher than that of the first law in those countries. It is also higher than the average level of independence in the 17 countries which had only one CB reform.

A preliminary examination of the factors that determine the level of legal independence chosen by political authorities suggests that being on the first fast track to join the EMU has a positive effect on legal independence, and that the later the year of $\mathrm{CB}$ reform the higher the level of independence embodied in the new charter. A possible reason is that the importance of CBI as a signal of financial respectability, to gain access to international credit markets, rose through the 1990 s with the further abolition of restrictions on capital flows and further widening of international capital markets. But the existing evidence does not support the view that countries with higher inflation subsequently grant higher independence to the CB.

The fact that the average level of legal independence of the new CBs of economies in transition is substantially higher than that of developed economies during the 1980s at least partially reflects the shift in professional consensus among economists and policymakers in favor of CBI between those two decades. Our feeling is that, had CB reform in the transition economies taken place during the 1980s rather than during the 1990s, the level of CBI embodied in the new laws would have been significantly lower. This is one concrete illustration of the broader principle that existing professional consensus at the time of reform affects the pattern of reform.

\section{Appendix}

Table 5 presents codings of the components of aggregate indices of legal CB independence. Table 6 presents yearly inflation rates and rates of depreciation in the real value of money $(D), 1989-1998$. Table 7 presents the cumulative liberalization index and Table 8 presents panel data for 3 subperiods. 
Table 5

Codings of the components of aggregate indices of legal central bank independence

\begin{tabular}{|c|c|c|c|c|c|c|c|c|c|c|c|c|c|c|c|c|c|}
\hline \multirow[t]{2}{*}{ Country } & \multirow{2}{*}{$\begin{array}{l}\text { Year of } \\
\text { enactment } \\
\text { of Central } \\
\text { Bank Law }\end{array}$} & \multicolumn{4}{|l|}{ CEO } & \multicolumn{3}{|c|}{ Policy formulation } & \multirow{2}{*}{$\begin{array}{l}\text { Objec- } \\
\text { tives }\end{array}$} & \multicolumn{8}{|c|}{ Limitations on lending } \\
\hline & & $\begin{array}{l}\text { Term of } \\
\text { office }\end{array}$ & $\begin{array}{l}\text { Who } \\
\text { appoints }\end{array}$ & $\begin{array}{l}\text { Dis- } \\
\text { missal }\end{array}$ & $\begin{array}{l}\text { Other } \\
\text { offices }\end{array}$ & $\begin{array}{l}\text { Who } \\
\text { for- } \\
\text { mulates }\end{array}$ & $\begin{array}{l}\text { Final } \\
\text { authority }\end{array}$ & $\begin{array}{l}\text { Role in } \\
\text { budget }\end{array}$ & & $\begin{array}{l}\text { Ad- } \\
\text { vances }\end{array}$ & $\begin{array}{l}\text { Securitized } \\
\text { lending }\end{array}$ & $\begin{array}{l}\text { Terms of } \\
\text { lending }\end{array}$ & $\begin{array}{l}\text { Potential } \\
\text { borrowers }\end{array}$ & $\begin{array}{l}\text { Type } \\
\text { of limit }\end{array}$ & $\begin{array}{l}\text { Maturity } \\
\text { of loans }\end{array}$ & $\begin{array}{l}\text { Interest } \\
\text { rates }\end{array}$ & $\begin{array}{l}\text { Primary } \\
\text { market }\end{array}$ \\
\hline Albania & 1992 & 0.75 & 0.75 & 0.83 & 0.50 & 0.67 & 0.20 & NA & 0.60 & 0.33 & 0.67 & 0.33 & NA & 0.33 & 1.00 & 0.75 & 0.00 \\
\hline \multirow[t]{2}{*}{ Armenia } & 1993 & 0.75 & 0.50 & 0.00 & 1.00 & 1.00 & 0.20 & 0.00 & 0.60 & 0.00 & 0.33 & 0.00 & 0.00 & 0.33 & 0.00 & 0.25 & 0.00 \\
\hline & 1996 & 0.75 & 0.50 & 0.83 & 1.00 & 1.00 & 1.00 & 1.00 & 1.00 & 1.00 & 0.67 & 0.67 & 0.67 & 0.33 & 0.67 & 1.00 & 1.00 \\
\hline \multirow[t]{2}{*}{ Azerbaijan } & 1992 & NA & 0.50 & 0.33 & 0.00 & 0.33 & NA & 0.00 & 0.60 & 0.00 & 0.00 & 0.00 & NA & NA & 1.00 & 0.25 & 0.00 \\
\hline & 1996 & 0.50 & 0.00 & 0.17 & 1.00 & 0.67 & NA & 0.00 & 0.40 & 0.00 & 0.00 & 0.33 & 0.33 & NA & 0.00 & 0.25 & 0.00 \\
\hline Belarus & 1992 & 0.75 & 0.50 & 1.00 & 1.00 & 0.67 & 0.80 & 1.00 & 0.80 & 1.00 & 0.33 & 0.67 & 0.33 & 0.00 & 1.00 & 0.25 & 1.00 \\
\hline Bulgaria & 1991 & 0.50 & 0.50 & 0.83 & 1.00 & 0.67 & NA & NA & 0.60 & 0.67 & 0.00 & 0.33 & NA & 0.33 & 1.00 & 0.25 & 1.00 \\
\hline Croatia & 1992 & 0.75 & 0.50 & 0.33 & 0.00 & 1.00 & 0.20 & 0.00 & 0.60 & 0.67 & 0.00 & 0.67 & NA & 0.33 & 0.67 & 0.25 & 0.00 \\
\hline $\begin{array}{l}\text { Czech } \\
\text { Republic }\end{array}$ & 1991 & 0.75 & 0.50 & 0.83 & 1.00 & 1.00 & 1.00 & NA & 0.80 & 0.67 & 0.67 & 0.67 & NA & 0.33 & 1.00 & 0.25 & 0.00 \\
\hline Estonia & 1993 & 0.50 & 0.50 & 0.83 & 1.00 & 1.00 & 1.00 & 1.00 & 0.80 & 1.00 & 1.00 & NA & NA & NA & NA & NA & 0.00 \\
\hline Georgia & 1995 & 0.75 & 0.50 & 0.83 & 1.00 & 1.00 & 0.40 & 1.00 & 0.60 & 1.00 & 0.67 & 0.67 & 1.00 & 0.33 & 1.00 & 0.75 & 0.00 \\
\hline Hungary & 1991 & 0.75 & 0.50 & 0.83 & 1.00 & 0.67 & 1.00 & 1.00 & 0.60 & 0.67 & NA & 0.33 & 1.00 & 0.33 & 0.33 & 0.75 & 0.00 \\
\hline \multirow[t]{2}{*}{ Kazakstan } & 1993 & 0.75 & 0.50 & 0.33 & 0.00 & 0.67 & 0.60 & 0.00 & 0.60 & 0.00 & 0.00 & 0.33 & 0.00 & NA & 0.67 & 0.75 & 0.00 \\
\hline & 1995 & 0.75 & 0.50 & 0.33 & 1.00 & 1.00 & 1.00 & 0.00 & 0.60 & 0.00 & 0.00 & 0.33 & 0.33 & NA & 0.00 & 0.75 & 1.00 \\
\hline $\begin{array}{l}\text { Kyrgyz } \\
\text { Republic }\end{array}$ & 1992 & 0.50 & 0.50 & 0.83 & 1.00 & 0.67 & 0.40 & 1.00 & 0.60 & 0.33 & 0.00 & 0.67 & NA & 0.00 & 1.00 & 0.25 & 1.00 \\
\hline Latvia & 1992 & 0.75 & 0.50 & 0.33 & 1.00 & 1.00 & 1.00 & 0.00 & 0.80 & 0.00 & 0.00 & 0.67 & NA & 0.33 & 1.00 & 0.25 & 0.00 \\
\hline \multirow[t]{2}{*}{ Lithuania } & 1991 & NA & 0.50 & 1.00 & 0.00 & 0.33 & 0.40 & 0.00 & 0.40 & 0.00 & 0.33 & 0.00 & 0.67 & 0.00 & 0.00 & 0.25 & 0.00 \\
\hline & 1996 & 0.50 & 0.50 & 0.83 & 1.00 & 1.00 & 1.00 & 1.00 & 0.80 & 1.00 & 1.00 & NA & NA & NA & NA & NA & 0.00 \\
\hline Macedonia & 1995 & 0.75 & 0.50 & 0.83 & 0.00 & 1.00 & 0.40 & 0.00 & 0.60 & 0.00 & 0.33 & 0.67 & 0.33 & 0.00 & 0.67 & 0.75 & 0.00 \\
\hline \multirow[t]{2}{*}{ Moldova } & 1991 & 0.75 & 0.50 & 0.83 & 1.00 & 1.00 & 0.80 & 0.00 & 0.60 & 0.00 & 0.00 & 0.33 & 0.00 & NA & 0.00 & 0.25 & 0.00 \\
\hline & 1995 & 0.75 & 0.50 & 0.83 & 1.00 & 1.00 & 1.00 & 1.00 & 0.80 & 1.00 & 0.00 & 0.33 & 0.67 & NA & 1.00 & 0.75 & 1.00 \\
\hline
\end{tabular}


Table 5 (continued)

\begin{tabular}{|c|c|c|c|c|c|c|c|c|c|c|c|c|c|c|c|c|c|}
\hline \multirow[t]{2}{*}{ Country } & \multirow{2}{*}{$\begin{array}{l}\text { Year of } \\
\text { enactment } \\
\text { of Central } \\
\text { Bank Law }\end{array}$} & \multicolumn{4}{|l|}{$\mathrm{CEO}$} & \multicolumn{3}{|c|}{ Policy formulation } & \multirow{2}{*}{$\begin{array}{l}\text { Objec- } \\
\text { tives }\end{array}$} & \multicolumn{8}{|c|}{ Limitations on lending } \\
\hline & & $\begin{array}{l}\text { Term of } \\
\text { office }\end{array}$ & $\begin{array}{l}\text { Who } \\
\text { appoints }\end{array}$ & $\begin{array}{l}\text { Dis- } \\
\text { missal }\end{array}$ & $\begin{array}{l}\text { Other } \\
\text { offices }\end{array}$ & $\begin{array}{l}\text { Who } \\
\text { for- } \\
\text { mulates }\end{array}$ & $\begin{array}{l}\text { Final } \\
\text { authority }\end{array}$ & $\begin{array}{l}\text { Role in } \\
\text { budget }\end{array}$ & & $\begin{array}{l}\text { Ad- } \\
\text { vances }\end{array}$ & $\begin{array}{l}\text { Securitized } \\
\text { lending }\end{array}$ & $\begin{array}{l}\text { Terms of } \\
\text { lending }\end{array}$ & $\begin{array}{l}\text { Potential } \\
\text { borrowers }\end{array}$ & $\begin{array}{l}\text { Type } \\
\text { of limit }\end{array}$ & $\begin{array}{l}\text { Maturity } \\
\text { of loans }\end{array}$ & $\begin{array}{l}\text { Interest } \\
\text { rates }\end{array}$ & $\begin{array}{l}\text { Primary } \\
\text { market }\end{array}$ \\
\hline \multirow[t]{2}{*}{ Mongolia } & 1991 & 0.50 & 0.50 & 1.00 & 0.00 & 1.00 & 1.00 & 0.00 & 0.80 & 0.00 & 0.00 & 0.67 & NA & NA & 0.00 & 0.25 & 0.00 \\
\hline & 1996 & 0.75 & 0.50 & 0.50 & 1.00 & 1.00 & 1.00 & 0.00 & 0.60 & 0.67 & 0.00 & 0.67 & 0.33 & 0.33 & 0.67 & 0.25 & 0.00 \\
\hline \multirow[t]{2}{*}{ Poland } & 1991 & 0.75 & 0.50 & 0.83 & 1.00 & 0.33 & 0.60 & 1.00 & 0.60 & 0.00 & 0.67 & 0.33 & 0.33 & 0.00 & 0.00 & 0.25 & 0.00 \\
\hline & 1997 & 0.75 & 0.50 & 0.83 & 1.00 & 1.00 & 1.00 & 1.00 & 0.60 & 1.00 & 1.00 & 1.00 & 1.00 & 1.00 & 1.00 & 1.00 & 1.00 \\
\hline Romania & 1991 & 0.00 & 0.50 & 0.33 & 1.00 & 0.67 & 0.40 & 0.00 & 0.40 & 0.33 & 0.00 & 0.33 & NA & 0.00 & 0.00 & 0.25 & 0.00 \\
\hline \multirow[t]{2}{*}{ Russia } & 1993 & 0.50 & 0.50 & 0.33 & 0.00 & 0.67 & 0.20 & 0.00 & 0.60 & 1.00 & 0.00 & 0.33 & NA & 0.00 & 1.00 & 0.25 & 0.00 \\
\hline & 1995 & 0.25 & 0.50 & 0.83 & 1.00 & 0.67 & 0.20 & 1.00 & 0.60 & 1.00 & 0.00 & 0.00 & 0.33 & NA & 0.00 & 0.75 & 0.00 \\
\hline $\begin{array}{l}\text { Slovak } \\
\text { Republic }\end{array}$ & 1992 & 0.75 & 0.50 & 0.67 & 1.00 & 1.00 & 1.00 & 0.00 & 0.60 & NA & 0.67 & 0.67 & 0.00 & 0.33 & 1.00 & NA & 0.00 \\
\hline Slovenia & 1991 & 0.75 & 0.50 & 1.00 & 1.00 & 1.00 & 0.40 & NA & 0.80 & 0.67 & 0.00 & 1.00 & NA & 0.00 & 0.67 & 0.25 & 0.00 \\
\hline Tajikistan & 1993 & NA & 0.50 & 0.50 & 0.00 & 0.67 & NA & 1.00 & 0.60 & 0.00 & 0.00 & 0.33 & 0.67 & NA & 0.00 & 0.25 & 0.00 \\
\hline Turkmenistan & 1992 & NA & 0.50 & 1.00 & 0.50 & 0.33 & 0.00 & 0.00 & 0.60 & 0.00 & 0.00 & 0.00 & 0.33 & NA & 0.00 & 0.25 & 0.00 \\
\hline Ukraine & 1991 & NA & 0.50 & NA & NA & 0.67 & NA & 1.00 & 0.60 & 0.00 & 0.00 & NA & NA & NA & NA & NA & NA \\
\hline \multirow[t]{2}{*}{ Uzbekistan } & 1992 & 0.25 & 0.50 & 0.50 & 1.00 & 0.67 & NA & 0.00 & 0.60 & 0.00 & 0.67 & 0.00 & 0.33 & 0.33 & 1.00 & 0.75 & 1.00 \\
\hline & 1995 & 0.25 & 0.50 & 0.83 & 0.00 & 1.00 & 1.00 & 1.00 & 0.60 & 1.00 & 0.00 & 0.00 & 0.00 & NA & 1.00 & 0.75 & 1.00 \\
\hline
\end{tabular}

Notes: 1. A detailed description of the 16 legal variables in the table appears in Table 1 of Cukierman et al. (1992, pp. 358, 359) or Table 19.1 of Cukierman (1992, pp. 373-376).

2. Although the 1997 charter of the Bank of Poland does not contain any reference to limitations on lending to government we assigned the maximum value of 1.00 to all the limitations on lending variables for Poland in 1997. The reason is that article 220-2 in the chapter on Public Finances (Chapter X) of the April 2, 1997 constitution of the Republic of Poland states that; "The budget shall not provide for covering a budget deficit by way of contracting credit obligations to the State's central bank".

3. The dates of enactment of the CB law in Ukraine and of the first law in Uzbekistan are tentative.

4. The first Russian CB law was passed in December 1990, apparently came into force only at the end of 1992 , was followed by the introduction of a new currency in mid-1993 and by the collapse of the Ruble zone at the end of 1993. In view of those gyrations we settled on 1993 as the year of enactment of the first Russian CB law. Unlike other CB charters the first Russian CB law was not translated into English by the IMF. The coding of this charter relies on a translation of relevant parts of this law from Russian by Daniel Treisman. 
Table 6

Yearly inflation rates and rates of depreciation in the real value of money $(D), 1989-1998$

\begin{tabular}{|c|c|c|c|c|c|c|c|c|c|c|c|c|c|c|c|c|c|c|c|c|}
\hline Country & 1989 & 1990 & 1991 & 1992 & 1993 & 1994 & 1995 & 1996 & 1997 & 1998 & 1989 & 1990 & 1991 & 1992 & 1993 & 1994 & 1995 & 1996 & 1997 & 1998 \\
\hline & \multicolumn{10}{|c|}{ Inflation - period averages in percentages $(100 \mathrm{~F})$} & & & & & \multicolumn{6}{|l|}{$D$} \\
\hline Ibania & 0 & 0 & 36 & 226 & 85 & 23 & 7.8 & 12.7 & 32.1 & 20.6 & .00 & 0.00 & 0.26 & 0.69 & 0.46 & 0.19 & .07 & 0.11 & .24 & 0.17 \\
\hline zerbaija & 0 & 7.8 & 107 & 912 & 1129 & 1664 & 411.7 & 19.7 & 8.4 & -0 . & 0 & 0.07 & 2 & 0.90 & 2 & 0.94 & .80 & 0.16 & .08 & -0.01 \\
\hline larus & 1. & 4.5 & 83.5 & 971 & 1187 & 2200 & 709.3 & 53 & 63.9 & 77 & .02 & 0.04 & 6 & 0.91 & 2 & 0.96 & .88 & 35 & 39 & 0.44 \\
\hline ulgaria & 6 & 22 & 333.5 & 82 & 73 & 96.3 & 62.1 & 123 & 1082 & 22 & 0.06 & 0.18 & 0.77 & 0.45 & 2 & 0.49 & 0.38 & 55 & 2 & 0.1 \\
\hline roa & 520.5 & 135.6 & 123 & 665.5 & 1517.5 & 97.6 & 2 & 3.5 & 3.6 & -1 & 0.96 & 0.58 & 0 & 0.8 & 0.9 & 0.49 & 2 & 33 & 3 & 0.05 \\
\hline Czech R & 2.3 & 10.8 & 56.6 & 11.1 & 208 & 10 & 9.1 & 8.8 & 8.5 & 10 & 2 & 0.1 & 0 & 0.10 & 0. & 0.09 & 0. & 8 & 8 & 0.10 \\
\hline Estonia & 6.1 & 23 & 210.5 & 1076 & 89.8 & 48 & 29 & 23 & 11 & 10 & & 0. & 0. & 0.91 & 0. & 0.32 & 2 & & 0 & 0.10 \\
\hline oor & 0 & 3.3 & 78 & 887 & 3125 & 15607 & 162.7 & 39.4 & 7.3 & & & 0. & 0 & 0. & 0.97 & 0.99 & 0.62 & 0.28 & 7 & 0.04 \\
\hline & 17 & 28.9 & 3 & 2 & 22.5 & 18.8 & & 23 & 3 & 14 & 5 & 0.2 & 0.2 & 0. & 0. & 0 & 2 & 9 & 5 & 0. \\
\hline $\mathrm{Ka}$ & 0 & 4.2 & 79 & 1381 & 1662 & 1892 & 176 & 39 & 17.4 & 7 & 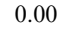 & 0.0 & 0. & 0. & 0.9 & 0 & 4 & 28 & 0.1 & $0 .($ \\
\hline Kyrgy & 0 & 3 & 85 & & 7 & 229 & & 30.4 & 25.5 & 13 & 0 & 0.03 & 0. & 0. & & 0 . & 0.34 & & 0. & 0.1 \\
\hline Lat & 4. & 10.5 & 172 & 9. & 1 & 36 & 25 & 17.6 & 8.4 & 4. & 0 & 0. & 0 & 0. & & 0 & 0 & & & 0.04 \\
\hline Lithuan & 2.1 & 8.4 & 224.7 & 1020.5 & 410.4 & 72.1 & 39.5 & 24.7 & 8.9 & 5. & 0.02 & 0.08 & 0.69 & 0.91 & 0 & 0.42 & 0.28 & 0.20 & 0.08 & 0.05 \\
\hline M & 1246 & 120.5 & 229.7 & 1664.4 & & 126.5 & 16.4 & 2.5 & 1.8 & 0.6 & & 0.55 & & 0.94 & & 0.56 & 4 & & & 0.01 \\
\hline & 0 & 4.2 & 9 & 127 & & 3. & 3 & 23.5 & 11.8 & 8 & & 0 & 0 & 0 & & 7 & & & & 0.07 \\
\hline & 0 & 0 & 208.6 & 321 & 18 & 12 & 56.8 & NA & NA & $\mathrm{N}$ & 0 & 0. & 0 & 0. & 0. & 0. & 0.36 & & $\mathrm{~N}$ & NA \\
\hline Russia & 2.2 & 5.6 & 93 & 1526 & 875 & 311.4 & 197.7 & 47.7 & 14.7 & 27.8 & 0.02 & 0.05 & 0.48 & 0.94 & 0.90 & 0.76 & 0.66 & 0.32 & 0.13 & 0.2 \\
\hline Slovak Republic & 0 & 10.8 & 61.2 & 10.1 & 23.2 & 13.4 & 9.9 & 5.8 & 6.1 & 6.7 & 0.00 & 0.10 & 0.38 & 0.09 & 0.19 & 0.12 & 0.09 & 0.05 & 0.06 & 0.06 \\
\hline Slovenia & 1306 & 550 & 117.7 & 207.3 & 32.9 & 21 & 13.5 & 9.9 & 8.4 & 8 & & 0.85 & & 0.67 & & 0.17 & 0.12 & 0.09 & 88 & 0.07 \\
\hline & 0 & 4 & 112 & 1157 & 2195 & 350 & 609 & & 87.8 & 43. & 0. & 0.04 & 0. & 0.92 & 0.96 & 0.78 & 0.86 & 0.81 & 0.47 & 0.3 \\
\hline $\mathrm{Tu}$ & 2. & 4.6 & 103 & & & 1748 & 1005 & 99 & & 17 & & 0. & & 0. & & 0. & 1 & 0.91 & 6 & 0. \\
\hline & 2 & 4 & 9 & 1210 & 4735 & & 3 & 8 & 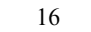 & 1 & & & & & & & .79 & 0.44 & 0 & 0 \\
\hline Uzbekistan & 0.7 & 3.1 & 82.2 & 645 & 534 & 1568 & 305 & 54 & 72 & 34 & 0.01 & 0.03 & 0.45 & 0.87 & 0.84 & 0.94 & 0.75 & 0.35 & 0.42 & 0.25 \\
\hline
\end{tabular}

Sources: 1. EBRD, Transition Report Update 1999.

2. de Melo et al. (1996).

$D$ is the rate of depreciation in the real value of money. It is calculated from the relation $D=F /(1+F)$ where $F$ is the average yearly rate of inflation in decimals.

The inflation data from 1992 onwards are from the 1999 EBRD Transition Report Update (the figures for 1998 are estimates as of July 1999).

The data for 1989 and 1990 are from de Melo et al. Except for Armenia, Belarus and Macedonia, whose data are from de Melo et al., the data for 1991 are from the EBRD (1999).

Data for Mongolia for all years are from de Melo et al. 
Table 7

Cumulative liberalization index $(\mathrm{CLI})^{\mathrm{a}}$

\begin{tabular}{|c|c|c|c|c|c|c|c|c|c|}
\hline Country & 1989 & 1990 & 1991 & 1992 & 1993 & 1994 & 1995 & 1996 & 1997 \\
\hline Albania & 0 & 0 & 0.24 & 0.9 & 1.6 & 2.3 & 3.04 & 3.78 & 4.56 \\
\hline Armenia & 0.04 & 0.08 & 0.21 & 0.6 & 1.02 & 1.44 & 1.93 & 2.65 & 3.37 \\
\hline Azerbaijan & 0.04 & 0.08 & 0.12 & 0.37 & 0.68 & 1.03 & 1.47 & 2.02 & 2.64 \\
\hline Belarus & 0.04 & 0.08 & 0.18 & 0.38 & 0.71 & 1.07 & 1.55 & 2.03 & 2.54 \\
\hline Bulgaria & 0.13 & 0.32 & 0.94 & 1.6 & 2.26 & 2.9 & 3.48 & 4.13 & 4.92 \\
\hline Croatia & 0.41 & 1.03 & 1.65 & 2.37 & 3.16 & 3.98 & 4.83 & 5.68 & 6.53 \\
\hline Czech Republic & 0 & 0.16 & 0.95 & 1.84 & 2.74 & 3.64 & 4.57 & 5.5 & 6.43 \\
\hline Estonia & 0.07 & 0.27 & 0.59 & 1.23 & 2.04 & 2.93 & 3.86 & 4.79 & 5.72 \\
\hline Georgia & 0.04 & 0.08 & 0.3 & 0.62 & 0.97 & 1.36 & 1.85 & 2.54 & 3.26 \\
\hline Hungary & 0.34 & 0.91 & 1.65 & 2.43 & 3.25 & 4.11 & 5.01 & 5.91 & 6.84 \\
\hline Kazakstan & 0.04 & 0.08 & 0.22 & 0.57 & 0.92 & 1.31 & 1.92 & 2.64 & 3.39 \\
\hline Kyrgyz Republic & 0.04 & 0.08 & 0.12 & 0.45 & 1.05 & 1.81 & 2.63 & 3.49 & 4.35 \\
\hline Latvia & 0.04 & 0.17 & 0.46 & 0.97 & 1.64 & 2.45 & 3.26 & 4.11 & 5 \\
\hline Lithuania & 0.04 & 0.17 & 0.5 & 1.05 & 1.83 & 2.72 & 3.61 & 4.5 & 5.39 \\
\hline Macedonia & 0.41 & 1.03 & 1.68 & 2.36 & 3.14 & 3.92 & 4.7 & 5.52 & 6.34 \\
\hline Moldova & 0.04 & 0.08 & 0.18 & 0.56 & 1.07 & 1.62 & 2.3 & 3.05 & 3.8 \\
\hline Mongolia & 0 & 0 & 0.44 & 0.99 & 1.6 & 2.27 & 2.94 & 3.61 & 4.44 \\
\hline Poland & 0.24 & 0.92 & 1.64 & 2.46 & 3.28 & 4.14 & 5.03 & 5.92 & 6.81 \\
\hline Romania & 0 & 0.22 & 0.58 & 1.03 & 1.61 & 2.29 & 3 & 3.72 & 4.47 \\
\hline Russia & 0.04 & 0.08 & 0.18 & 0.67 & 1.26 & 1.92 & 2.69 & 3.49 & 4.32 \\
\hline Slovak Republic & 0 & 0.16 & 0.95 & 1.81 & 2.64 & 3.47 & 4.33 & 5.19 & 6.05 \\
\hline Slovenia & 0.41 & 1.03 & 1.74 & 2.52 & 3.34 & 4.16 & 5.01 & 5.88 & 6.77 \\
\hline Tajikistan & 0.04 & 0.08 & 0.19 & 0.39 & 0.65 & 0.95 & 1.34 & 1.76 & 2.21 \\
\hline Turkmenistan & 0.04 & 0.08 & 0.12 & 0.25 & 0.41 & 0.63 & 0.85 & 1.17 & 1.53 \\
\hline Ukraine & 0.04 & 0.08 & 0.18 & 0.41 & 0.54 & 0.8 & 1.31 & 1.9 & 2.55 \\
\hline Uzbekistan & 0.04 & 0.08 & 0.12 & 0.38 & 0.68 & 1.11 & 1.69 & 2.26 & 2.83 \\
\hline
\end{tabular}

${ }^{a}$ CLI is composed of the cumulative degrees of liberalization in internal and external markets and private sector entry, with weights of $0.3,0.3$ and 0.4 , respectively.

Sources: Till 1995: de Melo et al. (1996); 1996-1997: update provided by Cevdet Denizer, World Bank, in July 1999.

Table 8

Panel data for 3 subperiods

\begin{tabular}{lllllllll}
\hline Country & Period & $D$ & LVAW & LVES & LVESX & CLl & WD & $l$ \\
\hline Albania & 1 & 0.24 & 0.00 & 0.00 & 0.00 & 0.12 & 0.00 & 0.10 \\
& 2 & NA & NA & NA & NA & NA & NA & NA \\
& 3 & 0.21 & 0.51 & 0.47 & 0.49 & 3.41 & 0.00 & 0.90 \\
Armenia & 1 & 0.50 & 0.00 & 0.00 & 0.00 & 0.21 & 1.00 & 0.20 \\
& 2 & 0.59 & 0.30 & 0.60 & 0.34 & 1.93 & 1.00 & 0.70 \\
& 3 & 0.09 & 0.85 & 1.00 & 0.90 & 3.37 & 0.00 & 0.80 \\
Azberbaijan & 1 & 0.48 & 0.00 & 0.00 & 0.00 & 0.12 & 1.00 & 0.00 \\
& 2 & 0.94 & 0.43 & 0.47 & 0.41 & 1.03 & 1.00 & 0.70 \\
Belarus & 3 & 0.26 & 0.24 & NA & 0.37 & 2.33 & 0.00 & 0.75 \\
& 1 & 0.47 & 0.00 & 0.00 & 0.00 & 0.18 & 0.00 & 0.10 \\
& 2 & 0.96 & 0.43 & 0.47 & 0.41 & 1.07 & 0.00 & 0.40 \\
& 3 & 0.51 & 0.73 & 0.75 & 0.67 & 2.29 & 0.00 & 0.75
\end{tabular}


Table 8 (continued)

\begin{tabular}{|c|c|c|c|c|c|c|c|c|}
\hline Country & Period & $D$ & LVAW & LVES & LVESX & $\mathrm{CLl}$ & WD & $l$ \\
\hline \multirow[t]{3}{*}{ Bulgaria } & 1 & 0.34 & 0.00 & 0.00 & 0.00 & 0.32 & 0.00 & 0.00 \\
\hline & 2 & NA & NA & NA & NA & NA & NA & NA \\
\hline & 3 & 0.48 & 0.55 & NA & 0.65 & 3.48 & 0.00 & 0.60 \\
\hline \multirow[t]{3}{*}{ Croatia } & 1 & 0.74 & 0.15 & 0.16 & 0.13 & 1.34 & 1.00 & 0.70 \\
\hline & 2 & NA & NA & NA & NA & NA & NA & NA \\
\hline & 3 & 0.26 & 0.44 & 0.60 & 0.49 & 5.26 & 1.00 & 0.90 \\
\hline \multirow[t]{3}{*}{ Czech Republic } & 1 & 0.16 & 0.00 & 0.00 & 0.00 & 0.16 & 0.00 & 0.00 \\
\hline & 2 & NA & NA & NA & NA & NA & NA & NA \\
\hline & 3 & 0.10 & 0.73 & 0.96 & 0.73 & 4.57 & 0.00 & 0.90 \\
\hline \multirow[t]{3}{*}{ Estonia } & 1 & 0.46 & 0.00 & 0.00 & 0.00 & 0.59 & 0.00 & 0.50 \\
\hline & 2 & NA & NA & NA & NA & NA & NA & NA \\
\hline & 3 & 0.19 & 0.78 & 0.96 & 0.58 & 4.79 & 0.00 & 0.90 \\
\hline \multirow[t]{3}{*}{ Georgia } & 1 & 0.47 & 0.00 & 0.00 & 0.00 & 0.30 & 1.00 & 0.30 \\
\hline & 2 & 0.81 & 0.00 & 0.00 & 0.00 & 1.61 & NA & 0.65 \\
\hline & 3 & 0.13 & 0.73 & 0.68 & 0.62 & 3.26 & 0.00 & 0.80 \\
\hline \multirow[t]{3}{*}{ Hungary } & 1 & 0.21 & 0.24 & 0.21 & 0.39 & 0.91 & 0.00 & 0.80 \\
\hline & 2 & NA & NA & NA & NA & NA & NA & NA \\
\hline & 3 & 0.17 & 0.67 & 0.79 & 0.61 & 5.01 & 0.00 & 0.90 \\
\hline \multirow[t]{3}{*}{ Kazakstan } & 1 & 0.47 & 0.00 & 0.00 & 0.00 & 0.22 & 0.00 & 0.10 \\
\hline & 2 & 0.79 & 0.32 & 0.63 & 0.56 & 1.62 & 0.00 & 0.65 \\
\hline & 3 & 0.17 & 0.44 & 0.92 & 0.79 & 3.39 & 0.00 & 0.80 \\
\hline \multirow[t]{3}{*}{ Kyrgyz Republic } & 1 & 0.45 & 0.00 & 0.00 & 0.00 & 0.12 & 0.00 & 0.00 \\
\hline & 2 & NA & NA & NA & NA & NA & NA & NA \\
\hline & 3 & 0.32 & 0.52 & 0.55 & 0.55 & 3.49 & 0.00 & 0.80 \\
\hline \multirow[t]{3}{*}{ Latvia } & 1 & 0.44 & 0.00 & 0.00 & 0.00 & 0.46 & 0.00 & 0.50 \\
\hline & 2 & NA & NA & NA & NA & NA & NA & NA \\
\hline & 3 & 0.15 & 0.49 & 0.96 & 0.73 & 4.11 & 0.00 & 0.90 \\
\hline \multirow[t]{3}{*}{ Lithuania } & 1 & 0.50 & 0.00 & 0.00 & 0.00 & 0.50 & 0.00 & 0.50 \\
\hline & 2 & 0.30 & 0.28 & 0.37 & 0.25 & 3.61 & 0.00 & 0.90 \\
\hline & 3 & 0.07 & 0.78 & 0.96 & 0.58 & 5.39 & 0.00 & 0.90 \\
\hline \multirow[t]{3}{*}{ Macedonia } & 1 & 0.65 & 0.15 & 0.16 & 0.13 & 2.36 & 0.00 & 0.80 \\
\hline & 2 & NA & NA & NA & NA & NA & NA & NA \\
\hline & 3 & 0.02 & 0.41 & 0.68 & 0.55 & 6.34 & 0.00 & 0.90 \\
\hline \multirow[t]{3}{*}{ Moldova } & 1 & 0.47 & 0.00 & 0.00 & 0.00 & 0.18 & 1.00 & 0.10 \\
\hline & 2 & 0.50 & 0.38 & 0.84 & 0.54 & 1.96 & 1.00 & 0.75 \\
\hline & 3 & 0.12 & 0.73 & 0.96 & 0.94 & 3.80 & 0.00 & 0.80 \\
\hline \multirow[t]{3}{*}{ Mongolia } & 1 & 0.23 & 0.00 & 0.00 & 0.00 & 0.00 & 0.00 & 0.00 \\
\hline & 2 & 0.59 & 0.43 & 0.96 & 0.61 & 2.27 & 0.00 & 0.70 \\
\hline & 3 & NA & 0.55 & 0.92 & 0.68 & 4.44 & 0.00 & 0.80 \\
\hline \multirow[t]{3}{*}{ Poland } & 1 & 0.66 & 0.10 & 0.27 & 0.19 & 0.92 & 0.00 & 0.70 \\
\hline & 2 & 0.22 & 0.46 & 0.49 & 0.32 & 4.59 & 0.00 & 0.90 \\
\hline & 3 & 0.11 & 0.89 & 0.92 & 0.95 & NA & 0.00 & NA \\
\hline \multirow[t]{3}{*}{ Romania } & 1 & 0.23 & 0.23 & 0.76 & 0.76 & 0.22 & 0.00 & 0.50 \\
\hline & 2 & NA & NA & NA & NA & NA & NA & NA \\
\hline & 3 & 0.50 & 0.34 & 0.51 & 0.32 & 3.00 & 0.00 & 0.80 \\
\hline \multirow[t]{3}{*}{ Russia } & 1 & 0.48 & 0.00 & 0.00 & 0.00 & 0.18 & 0.00 & 0.10 \\
\hline & 2 & 0.71 & 0.43 & 0.47 & 0.41 & 2.31 & 0.00 & 0.70 \\
\hline & 3 & 0.22 & 0.49 & 0.47 & 0.38 & 4.32 & 0.00 & 0.80 \\
\hline \multirow[t]{3}{*}{ Slovak Republic } & 1 & 0.14 & 0.00 & 0.00 & 0.00 & 0.56 & 0.00 & 0.45 \\
\hline & 2 & NA & NA & NA & NA & NA & NA & NA \\
\hline & 3 & 0.10 & 0.62 & 0.92 & 0.73 & 4.76 & 0.00 & 0.90 \\
\hline
\end{tabular}


Table 8 (continued)

\begin{tabular}{lllllllll}
\hline Country & Period & $D$ & LVAW & LVES & LVESX & CLl & WD & $l$ \\
\hline Slovenia & 1 & 0.77 & 0.15 & 0.16 & 0.13 & 1.03 & 1.00 & 0.70 \\
& 2 & NA & NA & NA & NA & NA & NA & NA \\
Tajikistan & 3 & 0.21 & 0.63 & 0.72 & 0.52 & 5.01 & 0.00 & 0.90 \\
& 1 & 0.49 & 0.00 & 0.00 & 0.00 & 0.19 & 1.00 & 0.10 \\
& 2 & 0.82 & 0.43 & 0.47 & 0.41 & 1.15 & 1.00 & 0.55 \\
Turkmenistan & 3 & 0.53 & 0.36 & NA & 0.29 & 2.21 & 1.00 & 0.70 \\
& 1 & 0.47 & 0.00 & 0.00 & 0.00 & 0.12 & 0.00 & 0.00 \\
& 2 & NA & NA & NA & NA & NA & NA & NA \\
Ukraine & 3 & 0.67 & 0.26 & 0.25 & 0.19 & 1.17 & 0.00 & 0.50 \\
& 1 & 0.49 & 0.00 & 0.00 & 0.00 & 0.18 & 0.00 & 0.10 \\
Uzbekistan & 2 & NA & NA & NA & NA & NA & NA & NA \\
& 3 & 0.47 & 0.42 & NA & NA & 1.90 & 0.00 & 0.70 \\
& 1 & 0.52 & 0.07 & 0.08 & 0.07 & 0.25 & 0.00 & 0.20 \\
& 2 & 0.75 & 0.41 & NA & 0.71 & 1.69 & 0.00 & 0.70 \\
& 3 & 0.34 & 0.56 & 0.92 & 0.92 & 2.83 & 0.00 & 0.60 \\
\hline
\end{tabular}

Notes:

(a) Period 1 starts in 1989. For non-former Soviet Union countries it ends in the year of enactment of the first central bank law. For former Soviet Union countries the last year of period 1 is the latest of the year of enactment of the first central bank law and the year of replacement of the Ruble by a domestic currency. Period 2 is the period after the enactment of the first central bank law including the year of enactment of the second central bank law, if there is such a law.

Periods 3 covers all the years following the enactment of the last central bank law, up to and including 1998. A consequence of this classification is that in former Soviet Union countries in which the Ruble continued to circulate after the enactment of the first CB law there may be three periods even if the country had only one CB reform. Even if the country had two reforms, the second period may differ from the period between the two laws.

(b) $D$ is the average rate of depreciation in the real value of money within each subperiod.

(c) CLI is the value of the cumulative liberalization index in the middle of each subperiod. If the number of years in a subperiod is odd, CLI is the value at the median year in that subperiod. If the number of years in a subperiod is even, CLI is the average of the values in the middle years.

Since the data for 1998 is unavailable, CLI for the third period of countries whose CB enactment year was 1996 (Armenia, Azarbaijan, Lithuania and Mongolia) is the value of CLI in 1997.

(d) WD is a war dummy which assumes a value of one in periods $(1,2$ or 3$)$ in which the country was at war for more than half of the period, and zero otherwise.

(e) $I$ is the value of the de Melo et al. (1996) index of liberalization of internal prices in the median year(s) of each subperiod.

(f) LVAW, LVES and LVESX are alternative proxies for aggregate legal CBI. Details appear at the beginning of Section 2.

\section{References}

Alesina, A., 1988. Macroeconomics and politics. NBER Macroeconomics Annual 3, 13-52.

Alesina, A., 1989. Politics and business cycles in the industrial democracies. Economic Policy 8, 57-98.

Alesina, A., Summers, L., 1993. Central bank independence and macroeconomic performance: some comparative evidence. Journal of Money, Credit and Banking 25, 151-162.

Bade, R., Parkin, M., 1988. Central bank laws and monetary policy. University of Western Ontario, October, Manuscript. 
Barro, R., 1979. On the determination of the public debt. Journal of Political Economy 82, 1095-1117.

Barro, R., 1984. Macroeconomics. Wiley, New York.

Conway, P., 1995. Currency Proliferation :The Monetary Legacy of the Former Soviet Union, Essays in International Finance, No. 197. International Finance Section, Princeton University, Princeton, NJ, June.

Cukierman, A., 1992. Central Bank Strategy, Credibility and Independence-Theory and Evidence. The MIT Press, Cambridge, MA.

Cukierman, A., 1998. The economics of central banking. In: Wolf, H. (Ed.), Contemporary Economic Issues: Macroeconomics and Finance (IEA Series). The Macmillan Press, Houndmills, Basingstoke, UK.

Cukierman, A., Webb, S., Neyapti, B., 1992. Measuring the independence of central banks and its effect on policy outcomes. The World Bank Economic Review 6, 353-0398.

Cukierman, A., Webb, S.B., 1995. Political influence on the central bank: international evidence. The World Bank Economic Review 9 (3), 397-423.

de Melo, M., Denizer, C., Gelb, A., 1996. From plan to market: patterns of transition. Policy Research Working Papers No. 1564, World Bank.

European Bank for Reconstruction and Development (EBRD) Transition Report, various issues.

European Bank for Reconstruction and Development (EBRD) Transition Update, various issues.

Eijffinger, S., De, H., 1996. The Political Economy of Central Bank Independence, Special Papers in International Economics No. 19. International Finance Section, Department of Economics, Princeton University, Princeton, NJ, May.

Eijffinger, S., van Keulen, M., 1995. Central bank independence in another eleven countries. Banca Nazionale del Lavoro Quarterly Review 192, 39-83.

Eijffinger, S., Schaling, E., 1993. Central bank independence in twelve industrial countries. Banca Nazionale del Lavoro Quarterly Review 184, 64-68.

Grilli, V., Masciandro, D., Tabellini, G., 1991. Political and monetary institutions and public financial policies in the industrial countries. Economic Policy 13, 341-392.

Haan, J. de, van't Hag, 1995. Variation in central bank independence across countries: some provisional empirical evidence. Public Choice 85, 335-351.

Haan, J. de, Kooi, W.J., 1998. Does central bank independence really matter? Department of Economics, University of Groningen, February.

Hinton-Braaten, K., 1994. New central banks. Manuscript, July.

Hochreiter, E., 1994. Central banking in economies in transition. In: Willet, T.D., Burdekin, R.C.K., Sweeney, R.J., Whilborg, C. (Eds.), Monetary Stability in Emerging Market Economies. The Westview Press, Boulder CO.

Hochreiter, E., Riesinger, S., 1995. Central banking in central and eastern Europe-selected institutional issues. ECU-Journal 32, 17-22.

Hochreiter, E., Rovelli, R., Winckler, G., 1996. Central banks and Seignorage: a study of three economies in transition. European Economic Review 40, 629-643.

Huterski, R., Nicholls, R., Wisniewski, Z., 1999. Monetary policy and independence of polish central bank. In: Healey, N.M., Wisniewski, Z. (Eds.), Central Banking in Transition Economies. Torun Business School, Poland.

Lewarne, S., 1995. The Russian central bank and the conduct of monetary policy. In: Willet, T.D., Burdekin, R.C.K., Sweeney, R.J., Whilborg, C. (Eds.), Monetary Stability in Emerging Market Economies. The Westview Press, Boulder, CO, pp. 167-192.

Loungani, P., Sheets, N., 1997. Central bank independence, inflation, and growth in transition economies. Journal of Money Credit and Banking 29, 381-399.

Melliss, C.L., Cornelius, M., 1994. New currencies in the former Soviet Union: a recipe for hyperinflation or the path to price stability? Working Paper Series No. 26, Bank of England, September.

Neyapti, B., 1997. Budget deficits and inflation: an analysis in light of the roles of central bank independence and financial market development. Unpublished $\mathrm{Ph} . \mathrm{D}$. Thesis, Department of Economics, University of Maryland. 
Neyapti, B., 2002. Central bank independence and economic performance in eastern Europe. Econ. Systems 26, 1.

Radzyner, O., Riesinger, S., 1997. Central bank independence in transition: legislation and reality in central and eastern Europe. Manuscript, Austrian National Bank.

Roubini, N., Sachs, J., 1989. Political and economic determinants of budget deficits in the industrial democracies. European Economic Review 33, 903-933.

Stern, N., 1996. The transition in eastern Europe and the former Soviet Union: some strategic lessons from the experience of 25 countries over 6 years. Elisha Pazner Memorial Lecture.

Wojtyna, A., 1997. Central bank independence and the constitution, Emergo. Journal of Transforming Economies and Societies 4, 49-55. 